\title{
PENGARUH GAYA KEPEMIMPINAN TRANSFORMASIONAL TERHADAP EFEKTIFITAS KINERJA PEGAWAI PUSKESMAS RAWAT INAP SIDOMULYO BARAT KOTA PEKANBARU
}

\author{
Trio Saputra, Pebriana Marlinda dan Wasiah Sufi \\ Universitas Lancang Kuning \\ Email : trio_saputra@unilak.ac.id
}

\begin{abstract}
Penelitian ini bertujuan untuk mengetahui dan menganalisis pengaruh gaya kepemimpinan transformasional terhadap efektifitas kinerja pegawai di Puskesmas Sidomulyo Kota Pekanbaru, Berdasarkan Undang-Undang Nomor 23 Tahun 1992 Tentang Kesehatan yang menekankan pentingnya upaya peningkatan mutu pelayanan kesehatan, khususnya ditingkat puskesmas dalam bentuk pelayanan kesehatan yang murah dan berkualitas, penelitian ini menggunakan metode survey melalui pendekatan kuantitatif. Pengumpulan data primer dilakukan melalui penyebaran kuesioner kepada keseluruhan populasi yang dijadikan sampel penelitian yang berjumlah 50 orang pegawai Puskesmas Sidomulyo Kota Pekanbaru analisis data menggunakan uji regresi linier sederhana dengan menggunkan program spss untuk melihat pengaruh dari variabel independen terhadap variabel dependen.

Hasil analisis data memperlihatkan ada pengaruh positif dan signifikan gaya kepemimpinan transformasional dengan efektivitas kinerja pegawai puskesmas sidomulyo barat kota pekanbaru. Hal itu ditunjukkan dengan nilai thitung sebesar 1,750 dengan $p=0,000<0,05$. diketahui bahwa nilai R2 (Rsquare) adalah sebesar 0,702. Hal ini berarti besarnya pengaruh dari gaya kepemimpinan transformasional terhadap efektifitas kinerja pegawai adalah sebesar $70.2 \%$ pengaruh yang positif dan signifikan gaya kepemimpinan transformasional dengan efektivitas kinerja pegawai memperlihatkan gaya kepemimpinan ini cocok diterapkan di puskesmas tersebut. Bekerjanya fungsi kepemimpinan transformasional ini pada peningkatan efektifitas kinerja berdasarkan upaya pemimpin untuk memberikan motivasi untuk meningkatkan prestasi dalam bekerja sebagai bagian dari organisasi sehingga pegawai mengembangkan kinerja dengan bersama-sama mewujudkan tujuan organisasi.
\end{abstract}

Keywords: Efektifitas Kinerja, Gaya Kepemimpinan Transformasional

\section{Abstrak}

This study aims to identify and analyze the effect of transformational leadership style of the effectiveness of employee performance in PHC Sidomulyo Pekanbaru, Based on Law No. 23 of 1992 on Health which emphasizes the importance of improving the quality of health services, especially the level community health centers in the form of health care cost and quality, this study used survey method with quantitative approach. Primary data were collected by distributing questionnaires to the entire population of the research sample numbering 50 employees Sidomulyo Pekanbaru City Health Center data analysis using simple linear regression by using SPSS program to see the effect of the independent variable on the dependent variable.

The results of data analysis showed there was a positive and significant influence transformational leadership style with health center staff performance effectiveness Sidomulyo western city of Pekanbaru. This is indicated by tcount amounted to 1,750 with $p=0.000<0.05$. note that the value of $R 2$ (Rsquare) amounted to 0,702. This means that the influence of transformational leadership style of the effectiveness of the performance of employees amounted to $70.2 \%$ positive and significant effect of transformational leadership style with employee performance demonstrated the effectiveness of leadership style is suitable to be applied in the health centers. The functioning of transformational leadership on improving the effectiveness of performance based leadership efforts to provide motivation to improve performance in working as part of the organization so that employees develop performance by jointly realize the objectives of the organization. 
Keywords: Effectiveness Performance, Transformational Leadership Style

\section{PENDAHULUAN}

Secara teori sebuah negara dibentuk oleh masyarakat di suatu wilayah yang bertujuan untuk memenuhi kebutuhan hidup bersama setiap anggotanya dalam koridor kebersamaan. Dalam angan setiap anggota masyarakat, negara yang dibentuk oleh mereka ini akan melaksanakan fungsinya menyediakan kebutuhan hidup anggota berkaitan dengan konstelasi hidup berdampingan dengan orang lain di sekelilingnya. Di kehidupan sehari-hari, kebutuhan bersama itu sering kita artikan sebagai "kebutuhan publik" salah satu contoh adalah kebutuhan publik yang mendasar adalah pelayanan kesehatan.

Pelayanan Kesehatan adalah pelayanan publik yang bersifat mutlak dan erat kaitannya dengan kesejahteraan masyarakat. Untuk semua pelayanan yang bersifat mutlak, negara dan aparaturnya berkewajiban untuk menyediakan layanan yang bermutu dan mudah didapatkan setiap saat. Salah satu wujud nyata penyediaan layanan publik dibidang kesehatan adalah adanya puskesmas. Tujuan utama dari adanya puskesmas adalah menyediakan layanan kesehatan yang bermutu namun dengan biaya yang relatif terjangkau untuk masyarakat, terutama masyarakat kelas ekonomi menengah kebawah.

Hal ini sesuai dengan undang-undang No.23 tahun 1992 tentang kesehatan menekankan pentingnya upaya peningkatan mutu pelayanan kesehatan, khususnya ditingkat puskesmas. Dijelaskan tentang kesehatan bahwa pelayanan kesehatan sangat dibutuhkan masyarakat terutama pelayanan kesehatan yang murah dan berkualitas.

Puskesmas rawat inap sodomulyo Kota Pekanbaru selaku penyelenggara layanan kesehatan di Kota Pekanbaru mengemban visi dan misi tercapainya kesehatan nasional yang murah dan berkualitas. Untuk dapat mencapai hal ini kinerja dari organisasi yang menjalankan sesuai dengan amanah dan tanggungjawab, tidak terlepas dari kinerja SDM pada sebuah organisasi yang dipengaruhi banyak faktor, diantaranya keterampilan atau keahlian yang dimiliki, kondisi atau situasi kerja, upah yang diterima, motivasi kerja, dan faktor kepemimpinan, setiap bidang kerja memerlukan penanganan atau perlakuan khusus. Sehubungan dengan itu dibutuhkan keterampilan atau keahlian khusus sesuai dengan bidang kerja yang ditangani. Seseorang yang memiliki keahlian atau keterampilan memadai akan dapat mempelancar pelaksanaan pekerjaannnya (Milner,1988) Pada kenyataannya, Puskesmas Rawat Inap Sidomulyo Kota Pekanbaru cukup lengang dan cenderung sepi. Hanya beberapa yang memanfaatkan fasilitas kesehatan di puskesmas tersebut. Bukan hanya itu, jumlah kunjungan perhari berdasarkan nomor entri di puskesmas tersebut hanya 94 layanan perhari, padahal jumlah penduduk di kecamatan tampan mencapai 200 ribu jiwa. Yang menjadi tanda tanya apakah masyarakat tidak puas dengan layanan atau masyarakat pekanbaru tidak ada lagi yang sakit (Halloriau.com, 27/05/2015). Terkait dengan kasus diatas dapat diteliti bahwa kinerja merupakan salah satu ukuran yang dapat digunakan untuk menilai baik buruknya sebuah organisasi atau perusahaan. Sebuah organisasi atau perusahaan dikatakan memiliki kinerja yang baik, apabila organisasi tersebut mampu menjalankan visi dan misinya sesuai dengan yang ditetapkan (Soeprihanto,2001) Efektif atau tidaknya kinerja seseorang dalam lingkungan kerjanya untuk dalam mencapai tujuan organisasi tidak lepas dari faktor lingkungan. Individu yang kurang nyaman atau kurangnya mendukung misalnya terjadi konflik yang selalu tinggi, dapat menggangu konsentrasi pegawai untuk bekerja. Konflik yang dimaksud dapat disebabkan dari luar diri pegawai seperti hubungan baik dengan rekan kerja atau dengan atasan dan bawahan (Gibson,1996) Kinerja bawahan dapat mencerminkan kepemimpinan dalam sebuah organisasi (Danim, 2004) kepemimpinan dikatan efektif pada sebuah organisasi apabila mampu meningkatkan kinerja bawahan dalam bekerja (Yulk,1994) sebuah organisasi mampu bertumbuh dan berkembang jika didukung dengan kepemimpinan efektif melalui seorang pemimpin yang tangkas, cerdas, cepat, arif bijaksana, dan mampu mengambil keputusan yang 
tepat. Kepemimpinan efektif dan produktif ini merupakan kekuatan dinamis yang dapat menumbuhkan motivasi, aspirasi, koordinasi, dan integrasi pada organisasi dalam pencapaian tujuan bersama yang telah ditetapkan (kartono, 2003) Kepemimpinan dalam sebuah organisasi berfungsi untuk memandu, menuntun, membimbing, membangun, memberi atau membangun motivasi-motivasi kerja, mengemudikan organisasi, menjalin komunikasi yang baik, melakukan pengawasan secara teratur, dan mengarahkan para pengikutnya kepada sasaran yang ingin dituju. Bawahan dan pengikut dalam sebuah oragnisasi, akan mampu bekerja dengan baik jika pemimpin dapat menjalankan peranan organisasi secara baik (Hanggoro,2002) Keberhasilan kepemimpinan pada sebuah organisasi dapat dilihat dari kemampuan pemimpin memotivasi bawahannya untuk dapat bekerja dengan baik. Selain itu, keberhasilan seorang pemimpin kecuali dapat dinilai dari produktivitas dan prestasi yang dicapainya, juga harus dinilai dari kebaikannya dan tidak boleh melakukan penghisapan oleh manusia terhadap manusia exploitation de I'homme par I'homme (Kartono, 2003).

Gaya kepemimpinan akan berpengaruh dalam mengarahkan setiap pegawai yang berada dalam unit pelayanan yang berbeda. Fungsi kepemimpinan dalam hal ini berperan mengarahkan, membimbing, dan menanamkan makna pelayanan yang diberikan kepada pasien sehingga pegawai bekerja secara profesional. Kesalahan yang dilakukan pegawai dapat disebabkan kuranganya pengarahan dan koordinasi yang diberikan pemimpin. Pengarahan yang dimaksud misalnya menyangkut uraian tugas, peran, dan fungsi setiap kategori baik berdasarkan jenjang atau jenis pendidikan pegawai maupun dari kualifikasi (Adikoesoemo, 1997) Ada berbagai gaya kepemimpinan yang ada, dari berbagai gaya kepemimpinan yang ada, karakteristik kepemimpinan yang sampai saat ini masih banyak dijadikan sebagai model dan masih sesuai dengan situasi saat ini seperti di puskesmas, adalah gaya kepemimpinan yang dikemukan Bass (dalam Yulk, 1994) yakni tipe kepemimpinan tranformasinal dan transaksional.

Dalam penelitian ini, peneliti hanya berfokus kepada gaya kepemimpinan transformasional karena karakteristik tipe kepemimpinan tranformasional pada penetapan dan pencapaian tujuan organisasi secara kolektif, target yang hendak dicapai merupakan keuntungan yang dapat dinikmati semua anggota, membangun hubungan saling percaya antara pemimpin dan bawahan, memberikan motivasi dan dorongan kepada bawahan agar dapat bekerja keras, meningkatkan tanggung jawab antar anggota, dan menumbuhkan komitmen bersama terhadap organisasi (Bass,1985). Tipe kepemimpinan tranformasional cenderung melibatkan para pegawai atau bawahan dalam mengelolah kinerja organisasi. Bawahan dianggap sebagai mitra kerja yang sejajar dan saling membutuhkan (Piccolo,2003) Senada dengan hal itu (Yammarino,1990) juga mengatakan Gaya kepemimpinan transformasional mengarahkan bawahan pada pencapaian moralitas dan motivasi yang tinggi. Bawahan yang terus dipacu secara terus menerus dapat meningkatkan produktivitas sekaligus kualitas hasil kerjanya. Penerapan gaya kepemimpinan ini menyadarkan bawahan untuk bekerja sesuai dengan prosedur dan target kerja yang telah ditentukan. Semakin kuat penerapan gaya kepemimpinan transformasional, maka semakin kuat pula semangat bawahan untuk memberikan hasil kerja yang terbaik pada perusahaan. Dengan gaya kepemimpinan ini, bawahan tidak perlu lagi mengandalkan perintah dan penjelasan atasan dalam melaksanakan tugas (Lievens et. al, 1997). Meskipun pelaksanaan tugas bawahan tidak dapat dilepaskan dari pengarahan dan penjelasan pimpinan, namun setidaknya ketergantungan pada hal tersebut dapat ditekan atau diminimalkan. Bawahan dapat melaksanakan tugas-tugasnya tanpa menunggu perintah dari pimpinan.

Berdasarkan uraian diatas, memperlihatkan ada banyak yang mempengaruhi efektifitas kinerja pegawai. Dari sejumlah faktor tersebut, penelitian ini secara khusus berfokus pada penelitian tentang pengaruh gaya kepemimpinan yakni transformasional terhadap efektifitas kinerja pegawai. Penerapan gaya kepemimpinan transformasional kepada pegawai puskesmas akan mempengaruhi kinerja pegawai. Gaya kepemimpinan transformasional memberikan kesempatan kepada pegawai untuk meletakkan keahlian dan keterampilan yang dimiliki. Selain itu rangsangan terhadap daya pikir berkembang sesuai dengan masalah-masalah yang ditemukan di lapangan. 


\section{METODE}

Penelitian ini dilaksanakan dengan metode survey melalui pendekatan kuantitatif. Secara teknis pelaksanaan metode survey dalam hal ini adalah dengan mengumpulkan data dari sampel penelitian yaitu pegawai puskesmas rawat inap sidomulyo Pekanbaru. Secara spesifik, pendekatan kuantitatif dalam penelitian ini adalah penelitian korelasional yang akan membuktikan asumsi terkait hubungan variabel independen terhadap variabel dependen (Husein, 2001). Selain itu, pendekatan penelitian ini juga dapat menjawab besarnya pengaruh variabel independen (gaya kepemimpinan tranformsional) terhadap variabel dependen (efektivitas kinerja) pada pegawai puskesmas rawat inap sidomulyo Pekanbaru. Teknik pengambilan sampel dalam penelitian ini dilakukan dengan metode sensus dimana seluruh populasi dijadikan sample. Analisa data dalam penelitian ini untuk membuktikan hipotesis terkait hubungan antara variabel bebas dengan menggunakan uji Regresi linier sederhana.

\section{HASIL DAN PEMBAHASAN}

Pengujian Persyaratan Analisis

1. Uji Normalitas

Uji normalitas diajukan pada masing-masing variabel yaitu variabel gaya kepemimpinan transformasional terhadap efektivitas kinerja Dari hasil analisis dapat dikatakan bahwa perhitungan kolmogorov smirnov Z (K-SZ) terhadap variabel gaya kepemimpinan transformasional K-SZ sebesar 1.163 dengan $\mathrm{P}=0.134(\mathrm{P}$ $>0.05$ ), sedangkan variabel efektivitas kinerja menunjukan K-SZ sebesar 0.855 dengan $\mathrm{P}=0.457(\mathrm{P}>$ 0.05 ) sehingga dapat disimpulkan bahwa kedua variabel mengikuti disteribusi normal.

\section{Uji Linearitas}

Berdasarkan hasil analisa data menggunakan SPSS dapat diketahui bahwa hasil perhitungan deviasi linieritas untuk gaya kepemimpinan transformasional terhadap efektivitas kinerja menghasilkan nilai $\mathrm{F}=$ 1.908 dengan $\mathrm{p}=0.058(\mathrm{p}>0.05)$ dengan demikian dapat disimpulakn bahwa pengaruh gaya kepemimpinan transformasional terhadap efektivitas kinerja linier.

3. Uji Regresi Linier Sederhana

Hipotesis dalam penelitian ini adalah "terdapat pengaruh yang signifikan antara gaya kepemimpinan transformasional terhadap efektivitas kinerja pegawai di puskesmas rawat inap sidomulyo barat kota Pekanbaru" Hasil pengolahan data analisis linear sederhana diketahui bahwa nilai koeisien regresi dari variabel gaya kepemimpinan transformasional (x) adalah sebesar 1,063. Nilai signifikansi dari variabel gaya kepemimpinan transformasional adalah 0,000. Jika nilai signifikansi dibandingkan dengan tingkat signifikan yang digunakan dalam penelitian ini alfa $(\alpha=0,05)$ maka terbukti bahwa nilai signifikansi lebih kecil dari pada tingkat signifikan yang digunakan $(0,000<0,05)$. Hal ini berarti terdapat pengaruh yang positif dari gaya kepemimpinan transformasional terhadap efektivitas kinerja pegawai di puskesmas rawat inap sidomulyo barat kota Pekanbaru. Dengan demikian hipotesis yang diajukan dapat diterima pada tingkat kepercayaan $95 \%$.

4. Koefisien Determinasi

Untuk mengetahui besarnya konstribusi variabel bebas terhadap variabel tergantung dapat dilihat dari nilai Rsquared pada output Model Summary (b) Berdasarkan hasil pengolahan data pada diketahui bahwa nilai R2 (Rsquare) adalah sebesar 0,702. Hal ini berarti besarnya pengaruh dari gaya kepemimpinan transformasional terhadap efektifitas kinerja pegawai adalah sebesar $70.2 \%$ dan sisanya sebesar $20.8 \%$ dijelaskan atau dipengaruhi oleh variabel lain yang tidak dimasukkan ke dalam penelitian. 
Hasil analisis data memperlihatkan ada pengaruh positif dan signifikan gaya kepemimpinan transformasional dengan efektivitas kinerja pegawai puskesmas sidomulyo barat kota pekanbaru. Hal itu ditunjukkan dengan nilai thitung sebesar 1,750 dengan $\mathrm{p}=0,000<0,05$. pengaruh yang positif dan signifikan gaya kepemimpinan transformasional dengan efektivitas kinerja pegawai memperlihatkan gaya kepemimpinan ini cocok diterapkan di puskesmas tersebut.

Hasil penelitian ini sesuai dengan penelitian Fuller et al (1999) mengenai gaya kepemimpinan transformasional dan transaksional di rumah sakit. Hasil penelitiannya menunjukkan gaya kepemimpinan transformasional berpengaruh terhadap peningkatan kinerja bawahan atau pegawai. Penerapan kepemimpinan transformasional mampu meningkatkan pemaknaan tugas yang diberikan atasan kepada bawahannya sehingga bawahan memiliki kompetensi yang lebih baik dan memiliki komitmen kerja yang kuat terhadap rumah sakit. Hal itu didukung Adikoesoemo (1997) yang mengatakan perhatian pimpinan pada bawahan seperti memberikan senyuman atau menyapa bawahan dapat menumbuhkan semangat kerja di antara pegawai. Menurutnya, pegawai yang bekerja melayani orang sakit membutuhkan dukungan dari orang-orang di sekitarnya khusunya pimpinan atau Kepala Ruangan yang membimbingnya.

Hal yang sama juga terjadi di puskesmas sidomulyo barat kota pekanbaru bahwa dengan penerapan gaya kepemimpinan transformasional mampu meningkatkan efektivitas kinerja pegawai. Berdasarkan analisis yang dilakukan, dari keempat faktor yang terkandung dalam gaya kepemimpinan transformasional yakni kharismatik, perhatian terhadap individu, perangsangan intelektual, dan motivasi inspirasional, hanya faktor perhatian terhadap individu dan dan motivasi inspirasional yang berpengaruh terhadap efektivitas kinerja karyawan. Pengaruh faktor perhatian terhadap individu sebagai bagian dari gaya kepemimpinan transformasional menunjukkan pentingnya perhatian yang diberikan seorang pemimpin kepada bawahan. Pemimpin yang memberikan perhatian individu misalnya mengajak berbicara ketika pegawai mengalami kesulitan, menyapa dan memberikan senyuman kepada pegawai, dapat meningkatkan efektivitas kinerja pegawai. Hal itu didukung Davis (1972) yang menyatakan, setiap bawahan pada perusahaan membutuhkan perhatian dari pemimpinnya. Perhatian tersebut dapat dilakukan dengan berbagai cara misalnya menanyakan kesulitan-kesulitan yang dialami bawahan dalam menjalankan pekerjaannya. Dengan melakukan hal tersebut, bawahan merasa diperhatikan dan akan timbul motivasi bekerja secara lebih baik. Gaya kepemimpinan transformasional salah satunya mampu menumbuhkan perangsangan intelektual.

Hasil penelitian memperlihatkan gaya kepemimpinan transformasional di puskesmas sidomulyo barat kota pekanbaru mampu merangsang intelektual pegawai. Perangsangan intelektual yang dimaksud adalah kemampuan berpikir pegawai semakin diasah. Berkembangnya kemampuan intelektual pegawai akan memampukannya untuk mengatasi kesulitan-kesulitan yang dihadapi. Dalam menjalankan tugastugasnya, pegawai tidak terluput dari banyak kesulitan baik yang datang dari dalam diri maupun yang berasal dari luar diri misalnya berhadapan dengan pasien. Pelayanan kesehatan membutuhkan ketelitian dan kecermatan karena menyangkut nyawa pasien. Metode-metode yang diterima pegawai selama dalam pendidikan tidak cukup dalam menjalankan tugas-tugasnya karena dunia kesehatan atau penyakit senantiasa berkembang. Pegawai tidak cukup hanya mengandalkan materi yang pernah diterima tetapi juga harus senantiasa mengembangkan ketrampilannya, mengasah kemampuan intelektualnya sehingga mampu mengatasi kesulitan yang dihadapi.

Selain perhatian individu dan perangsangan intelektual, gaya kepemimpinan transformasional juga mampu menumbuhkan motivasi inspirasional pada pegawai di puskesmas sidomulyo barat kota pekanbaru. Pegawai perlu senantiasa memiliki motivasi yang baik dan didasarkan atas tanggung jawab dalam menjalankan pekerjaannya. Pegawai yang kurang memiliki motivasi dalam bekerja, akan menganggap pekerjaannya sebagai beban dan rutinitas. Oleh karena itu, tidak akan ada upaya untuk meningkatkan pelayanan yang lebih baik. Hal ini dapat merugikan pihak puskesmas dan khususnya 
pasien. Motivasi yang rendah dari pegawai dapat mengakibatkan terjadinya banyak kesalahan dalam melayani pasien misalnya salah memberikan obat, tidak melakukan kontrol secara teratur pada pasien. Hal itu didukung Fiedler (1966) yang menyatakan motivasi rendah dari seorang karyawan akan menghasilkan hasil kerja yang kurang baik karena dalam menjalankan pekerjaannya cenderung asalasalan.

Berdasarkan hasil penelitian memperlihatkan gaya kepemimpinan transformasional yang diterapkan di puskesmas sidomulyo barat kota pekanbaru menurut penilaian pegawai mampu menumbuhkan motivasi bagi pegawai. Motivasi yang dimaksud misalnya berusaha untuk melaksanakan tugas-tugas dengan sebaik-baiknya meskipun tidak diawasi oleh Kepala Ruangan. Motivasi pegawai untuk bekerja sebaik-baiknya terkait dengan kesempatan yang diberikan oleh pemimpin kepada pegawai pada saat menjalankan pekerjaan. Pemimpin atau Kepala Ruang tidak bertindak sebagai bos tetapi menempatkan diri sejajar dengan pegawai lain. Artinya, pemimpin juga melakukan atau menangani hal yang sama jika pegawai lainnya berhalangan. Contoh yang diberikan pemimpin ini dapat menumbuhkan motivasi bagi pegawai untuk melakukan hal yang sama.

Pengaruh gaya kepemimpinan transformasional dalam meningkatkan efektivitas kinerja pegawai di puskesmas sidomulyo barat kota pekanbaru juga didukung oleh Yukl (1994). Menurutnya, seorang pimpinan perlu memberikan kesempatan kepada bawahan untuk melakukan pekerjaannya tanpa mengalami tekanan. Gaya kepemimpinan yang mengedepankan kemitraan, dimana bawahan tidak dianggap sebagai suruhan, efektif untuk memberdayakan bawahan dalam sebuah organisasi. Hal yang sama juga dikemukakan Gibson et. al (1996) yang mengatakan seorang pemimpin diharapkan mampu memberikan inspirasi dan motivasi pada bawahannya untuk mencapai hasil lebih baik dari yang direncanakan. Penerapan gaya kepemimpinan transformasional mampu mempengaruhi persepsi, sikap, dan perilaku bawahan ke arah peningkatan pengetahuan, wawasan dan kemampuan dalam menjalankan organisasi. Penekanan pada proses perubahan tersebut tidak hanya dimaksudkan untuk menghadapi kondisi saat ini saja tetapi juga masa yang akan datang. Hal ini berhubungan dengan visi Puskesmas. Maka pihak puskesmas perlu menyiapkan diri dari berbagai aspek terutama dari segi kepemimpinan.

Hal itu dapat dicontohkan dengan kesalahan dokter dalam mendiagnosa pasien dan memberikan dosis obat yang terlalu tinggi. Dalam hal ini pemimpin harus mampu memberikan arahan yang tepat kepada pegawai agar mampu berpikir kritis jika menemukan kesalahan yang dapat membahayakan pasien. Dengan menerapkan gaya kepemimpinan transformasional, pegawai dapat semakin terampil menangani kasus-kasus yang dihadapi sehari-hari.Selain itu, gaya kepemimpinan transaksional yang signifikan terhadap efektivitas kinerja pegawai dapat dikaitkan dengan budaya Timur yakni cenderung masih mementingkan penghargaan dan pujian dalam bekerja. Namun bukan berarti pegawai dalam bekerja tidak mementingkan imbalan gaji. Gaji juga tetap dibutuhkan pegawai tetapi kenyamanan dalam bekerja ternyata masih lebih diutamakan pegawai. Hal ini didukung oleh Kuswadi (2004) yang mengatakan bahwa kepuasan karyawan dalam bekerja tidak hanya diukur dari besarnya gaji yang diterima. Kepuasan banyak juga dipengaruhi perhatian dari pimpinan atau penghargaan yang diberikan atasan kepada pekerjaan yang dihasilkan. Bahkan menurut Kuswadi (2004) hal semacam ini juga berlaku di tingkat manajer yang masih sering lebih mementingkan penghargaan, pujian, dan sanjungan dalam bekerja. Hal-hal semacam ini dapat memberikan rasa nyaman bagi karyawan dalam bekerja. Hal yang sama juga terjadi pada para pegawai di puskesmas sidomulyo barat kota pekanbaru yang tidak menempatkan gaji atau imbalan sebagai faktor paling utama tetapi lebih kepada kenyamanan dalam bekerja seperti ditunjukkan dalam gaya kepemimpinan transformasional.

Dari hasil analisis penelitian memperlihatkan bahwa gaya kepemimpinan transformasional berpengaruh terhadap efektivitas kinerja pegawai. Hasil penelitian ini sesuai dengan hasil penelitian Fuller et. al (1999). Dari hasil penelitian yang dilakukannya, menunjukkan gaya kepemimpinan transformasional berpengaruh lebih kuat dalam meningkatkan kompetensi pegawai dibandingkan dengan 
gaya kepemimpinan transaksional. Hal ini terkait dengan gaya kepemimpinan transaksional yang lebih mengedepankan target secara eksplisit dan perlakuan terhadap bawahan sebagai upahan. Pola kepemimpinan transaksional dapat menghambat daya pikir pegawai sehingga dalam menjalankan pekerjaannya cenderung dilaksanakan secara kaku. Kurangnya pengaruh gaya kepemimpinan transaksional di puskesmas sidomulyo barat kota pekanbaru karena dalam menjalankan tugas-tugas pelayanan, pegawai juga dituntut agar berpikir kritis sehingga tugas-tugas yang hendak dijalankan juga masih mungkin untuk dikonsultasikan kembali kepada pihak terkait seperti dokter terutama muncul suatu keragu-raguan dalam diri pegawai.

Berdasarkan uraian di atas, dapat ditarik kesimpulan bahwa gaya kepemimpinan transformasional yang diterapkan di puskesmas sidomulyo barat kota pekanbaru telah mampu meningkatkan efektivitas kinerja pegawai. Hal itu dapat dilihat dari meningkatnya ketrampilan pegawai dalam menjalankan tugas-tugasnya. Pegawai juga semakin mampu mengatasi setiap kesulitan yang ditemukan di lapangan. Selain itu, pegawai mampu menjalankan tugas-tugasnya secara bertanggung jawab karena Kepala puskesmas selama ini memperlakukan pegawai sebagai mitra yang juga harus bertanggung jawab terhadap pekerjaan yang dijalankan.

\section{KESIMPULAN}

Berdasarkan hasil penelitian yang dilakukan pada pegawai puskesmas rawat inap sidomulyo barat kota Pekanbaru, maka dapat dibuat kesimpulan hasil penelitian, sebagai berikut :

1. Terdapat pengaruh yang signifikan antara gaya kepemimpinan transformasional terhadap efektifitas kinerja pegawai puskesmas rawat inap sidomulyo barat kota pekanbaru. Bekerjanya fungsi kepemimpinan transformasional ini pada peningkatan efektifitas kinerja berdasarkan upaya pemimpin untuk memberikan motivasi untuk meningkatkan prestasi dalam bekerja sebagai bagian dari organisasi sehingga pegawai mengembangkan kinerja dengan bersama-sama mewujudkan tujuan organisasi.

2. Hasil penelitian memperlihatkan faktor peningkatan prestasi kerja dalam kepemimpinan di puskesmas rawat inap sidomulyo barat berpengaruh positif signifikan terhadap efektivitas kinerja pegawai. Oleh karena itu, pihak puskesmas lebih memberikan kepercayaan dan reward kepada pegawai terhadap pegawai dalam menjalankan tugasnya dan pihak puskesmas lebih banyak memberikan peluang kepada pegawai dalam memberikan suara dan pendapat sebagai bahan pertimbangan dalam menentukan kebijakan puskesmas. Dan pihak puskesmas lebih menekankan kemampuan pemimpin yang mampu melakukan pendekatan secara individu seperti memberikan arahan secara individu, dan kemampuan menumbuhkan motivasi inspirasional pegawai misalnya menumbuhkan motivasi yang positif dalam diri pegawai seperti penghayatan terhadap nilai-nilai kerja dan tanggung jawab.

\section{DAFTAR PUSTAKA}

[1]. Danim, Sudarwan. (2004).Motivasi Kepemimpinan dan Efektivitas Kelompok. Jakarta: Rineka Cipta.

[2]. Kerlinger, Fred, N. (2004). Azas-azas Penelitian Behavioral (Penerjemah : Landung R. Simatupang). Yogyakarta: BPFE-UGM.

[3]. Kuswadi. (2004). Cara mengukur kepuasan karyawan. Jakarta: PT. Elex Media Komputindo.

[4]. Saputra, T. (2016). Pengaruh Motivasi Kerja Terhadap Disiplin Kerja Pegawai Pada Dinas Pemuda Dan Olahraga Provinsi Riau. Jurnal Niara, 8(2), 50-60. 
[5]. Umar, Husein. 2010. Desain Penelitian MSDM dan Perilaku Karyawan. Jakarta : PT Raja Grafindo Persada

[6]. Wibowo. (2013). Perilaku dalam Organisasi. Jakarta: Rajawali Pers. 